\title{
BUMDESMA EMPOWERMENT IN WARUNGKIARA VILLAGE, SUKABUMI TO BECOME AN INDEPENDENT VILLAGE
}

\author{
DEWI GUNHERANI \\ Prodi Akuntansi S1, Fakultas Ekonomi, Universitas Pamulang \\ dosen01941@unpam.ac.id
}

\begin{abstract}
Bundesma empowerment is the process of developing a village's economy. This program took the initiative to start a process of Social Economy activities that could improve the economic situation and conditions of the village community in Sukabumi, especially in the Warungkiara. In the Empowerment activities, the participation of the Bundesma and the village community as a driving force for economic development is overseen by the Government. The main objective of empowering Bundes and Bundesma is an independent village. This activity intends that rural communities in the Warungkiara area can turn their village into an independent village. The definition of an Independent Village is a village that is able to manage the economy of each citizen without the assistance of other parties. The creation of this condition reflects the strong willingness of the people of the village to move forward, the village that produces their products / works that are proud of and the ability of the village to meet their needs. In empowering Bundes and Bundesma there are several problems that hamper them including; Difficulties in product marketing, financial limitations and limited human resources (HR). In this study, the researchers used qualitative naturalistic methods. Qualitative naturalistic is a method that is carried out in the actual conditions that occur at the research location. This research method offers convenience and freedom for researchers to obtain accurate information from informants in the warungkiara sub-district. The results showed that in Warungkiara sub-district there were 12 Bundes in 12 villages and 2 Bundesma.
\end{abstract}

Keywords : Empowerment, Bundes, qualitative, marketing, financial, HRD

\section{PENDAHULUAN}

\section{Pengertian BUMDes}

Adalah badan usaha yang seluruh atau sebagian modalnya dimiliki oleh desa melalui penyertaan secara langsung yang berasal dari kekayaan desa yang dipisahkan guna mengelola asset, jasa pelayanan, dan usaha lainnya untuk sebesar-besarnya kesejahteraan masyarakat desa sebagaimana dimaksud dalam Undang Undang no 6 Tahun 2014 tentang desa. 
Selanjutnya keberadaan Bundes diakui sebagai Badan Usaha Milik Desa berdasarkan pada Undang-Undang No. 32 Tahun 2004 tentang Pemerintahan Daerah pasal 213 menyebutkan bahwa BUMDes adalah badan hukum . Dalam perekonomian Indonesia UMKM merupakan kelompok usaha yang memiliki jumlah paling besar dan terbukti tahan terhadap berbagai macam goncangan krisis ekonomi. Terkait dengan Bundesma yang terdapat di Warungkiara Sukabumi merupakan usaha UMKM , Pelaku usaha tergabung dalam pemberdayaan usaha rakyat yang diwujudkan dalam Badan usaha milik desa (BUMDES) lokal dan kawasan serta Badan usaha mililik desa bersama (BUMDESMA). Dengan adanya Badan usaha milik desa ini sangat berarti bagi kesejahteraan masyarakat desa, karena memberikan manfaat yang begitu besar seperti mampu membantu masyarakat dalam mengenal dan memanfaatkan potensi yang ada, membuka lapangan pekerjaan, dan lain sebagainya. Pada dasarnya Badan usaha milik desa bertujuan untuk mensejahterakan dan menghidupkan perekonomian desa. Sehingga desa akan mampu menopang perkembangan perkeonomian negara. Hal ini bisa terjadi karena memang desa merupakan unit terkecil namun memiliki peran penting dalam negara.

Di wilayah Warungkiara ini terdapat 2 Bundesma yaitu Garuda Jaya dan Kiara Mandiri yang memiliki pabrik tapioka. Kelompok Tani pemilik kebun singkok menjual singkok ke Bundes atau Bundesma untuk diproses menjadi tapioka.

\section{Pemberdayaan Bundes}

Bumdes merupakan salah satu lembaga ekonomi yang diharapkan dapat menjadi salah satu yang berkontribusi pada sumber pendapatan desa. Dalam Pemberdayaan masyarakat tersebut tampak partisipasi Bundes dan masyarakat desa sebagai agen pembangunan yaitu motor pengerak pembangunan ekonomi dikawal oleh Pemerintah Desa.

Sebagaimana disebutkan di atas bahwa di kecamatan Warungkiara terdapat 12 Bundes di 12 desa dan 2 Bundesma yaitu :

1. Bundes desa Hegarmanah

2. Bundes desa Bantarkalong

3. Bundes desa Dinarjaya

4. Bundes desa Sirmajaya

5. Bundes desa Ubrug

6. Bundes desa Girijaya

7. Bundes desa Warungkiara

8. Bundes desa Sukaharja

9. Bundes desa Tarisi

10. Bundes desa Damaraja

11. Bundes desa Kertamukti

12. Bundes desa Mekarjaya

Di samping itu terdapat 2 Bundes Bersama (Bundesma) yaitu :

1. Bundesma Garuda Jaya

2. Bundesma Kiara Mandiri 
Di Kabupaten Sukabumi terdapat 2 Bundesma kawasan mendapatkan perhatian khusus (diprioritaskan) oleh pemerintah, yang mana satu di antaranya berada di Kecamatan Warungkiara yaitu :

a. Bundesma Sitaman Sakti yang ditetapkan Unisco sebagai Kawasan nasional. Bundes ini inisiatif dari Pemerintah Pusat yi program 2020 ada berbagai bantuan dari kementrian terkait di antaranya akan dibangun Pasar Desa dan programnya argo wisata yaitu budi daya manga.

b. Bundesma Kiara Mandiri yang merupakan usaha UMKM masyarakat Desa dikecamatan Warungkiara dilakukan oleh kelompok-kelompok tani yang bercocok tanam singkok yang menjual hasil panennya kepada Bundesma yang mengolah menjadi Industry tapioca.

Pemberdayaan Bundes dan Bundesma tersebut ditujukan agar masyarakat pedesaan diwilayah kecamatan Warungkiara menuju Desa Mandiri. Desa Mandiri sebagaimana dikemukakan oleh Lendy W Wibowo, "Desa Mandiri itu mencerminkan kemauan masyarakat Desa yang kuat untuk maju, Desa yang menghasilkannya produk/karya Desa yang membanggakan dan kemampuan Desa memenuhi kebutuhan-kebutuhannya." Dalam istilah lain, Desa mandiri bertumpu pada trisakti Desa yaitu;
a. karsa,
b. karya,
c. sembada.

Jika Trisakti Desa dapat dicapai maka Desa itu disebut sebagai Desa berdikari, yaitu kondisi Desa yang mencakup bidang ekonomi, budaya dan sosial bertumpu pada tiga daya yakni :

a. berkembangnya kegiatan ekonomi Desa dan antar Desa,

b. makin kuatnya sistem partisipatif Desa, serta

c. terbangunnya masyarakat di Desa yang kuat secara ekonomi dan sosial-budaya serta punya kepedulian tinggi terhadap pembangunan serta pemberdayaan Desa.

\section{Permasalahan yang dihadapi oleh Bundesma}

Dalam memberdayakan Bundes dan Bundesma dikecamatan Warungkiara Kabupaten Sukabumi terdapat beberapa persoalan yaitu :

1. Kesulitan pemasaran

Sebagaimana usaha yang berskala kecil Salah satu aspek yang terkait dengan masalah pemasaran yang umum dihadapi oleh pengusaha UKM adalah tekanan-tekanan persaingan, baik dipasar domestik dari produkproduk yang serupa buatan pengusaha-pengusaha besar dan impor, maupun dipasar ekspor.

2. Keterbatasan finansial

Bundesma di Warungkiara menghadapi dua masalah utama dalam aspek finansial antara lain:

a. modal (baik modal awal maupun modal kerja) 
b. Finansial jangka Panjang untuk investasi yang sangat diperlukan untuk pertumbuhan output jangka panjang.

Keterbatasan modal sebenarnya dapat diatasi dengan bergandengan tangan dengan bank ataupun pemerintah yang saat ini sedang getol-getolnya melempar program mengentaskan kemiskinan. Untuk dapat mengikuti program pemerintah maupun pinjaman ke bank para pelaku harus mempunyai kapasitas membuat laporan keuangan. Persoalannya di sini para petani maupun anggota Bundes sebagian besar tidak mencatat setiap transaksi yang dilakukan, sehingga tidak bankable.

3. Keterbatasan Sumber Daya Manusia (SDM)

Keterbatasan sumber daya manusia juga merupakan salah satu kendala serius bagi Bundesma di Warungkiara, terutama dalam aspek-aspek kewirausahaan, manajemen, teknik produksi, pengembangan produk, control kualitas, akuntansi, Semua keahlian tersebut sangat diperlukan untuk mempertahankan atau memperbaiki kualitas produk, meningkatkan efisiensi dan produktifitas dalam produksi, memperluas pangsa pasar dan menembus pasar baru.

\section{METODE RISET}

\section{Tempat dan Waktu Penelitian}

a. Tempat Penelitian Bumdes dan Bundesma serta masyarakat desa yang berada di Kecamatan Warungkiara Sukabumi.

b. Waktu Penelitian Waktu penelitian adalah rentang waktu yang digunakan untuk melaksanakan penelitian sejak dari awal hingga selesai. Adapun waktu penelitian ini akan dilaksanakan selama lima bulan, yaitu dari bulan September 2019 sampai dengan Januari 2020.

\section{Alasan penelitian menggunakan metode kualitatif}

a. Secara umum metode penelitian diartikan sebagai cara ilmiah untuk mendapatkan data dengan tujuan dan kegunaan tertentu, Sugiyono (2012:3). Dan dalam penelitian ini peneliti menggunakan metode kualitatif atau naturalistik karena dilakukan pada kondisi yang alamiah dan kualitatif menawarkan kemudahan dan kebebasan untuk mendapatkan informasi dari key informan sebagai data yang akurat. Dan Moleong (2010:35) menyatakan bahwa penelitian kualitatif merupakan penelitian yang bermaksud untuk memahami fenomena tentang apa yang dialami oleh subyek penelitian, misalnya perilaku, persepsi, motivasi, tindakan yang dilakukan secara holistik dan dengan cara deskriptif.

b. Sebagaimana yang menjadi corak penelitian deskriptif kualitatif, bahwa penelitian kualitatif tidak hanya menetapkan penelitiannya hanya berdasarkan variabel penelitian, tetapi keseluruhan situasi sosial yang diteliti yang meliputi aspek tempat (place), pelaku (actor) dan aktivitas (activity) yang berinteraksi secara sinergis, Sugiyono (2012:287). 
c. Adapun pendekatan yang dilakukan dalam penelitian ini adalah pendekatan studi kasus. Menurut Creswell dalam Sugiyono (2012:14), Studi kasus merupakan salah satu jenis penelitian kualitatif, dimana peneliti melakukan eksplorasi secara mendalam terhadap program, kejadian, proses, aktivitas, terhadap satu atau lebih orang. Suatu kasus terikat oleh waktu dan aktivitas dan peneliti melakukan pengumpulan data secara mendetail dengan menggunakan berbagai prosedur pengumpulan data dan dalam waktu yang berkesinambungan. Ada beberapa karakteristik dari suatu studi kasus, yaitu:

1) Mengidentifikasi kasus untuk suatu studi kasus.

2) Kasus tersebut adalah sebuah sistem yang terkait oleh waktu dan tempat.

3) Studi kasus menggunakan berbagai sumber informasi dalam pengumpulan data untuk memberikan gambaran secara terinci dan mendalam tentang respons dari suatu peristiwa.

d. Peneliti akan menghabiskan waktu dalam menggambarkan konteks atau setting dalam suatu kasus, karena suatu kasus dapat dikaji menjadi suatu objek studi maupun mempertimbangkannya menjadi sebuah metodologi.

e. Adapun jumlah populasi dalam penelitian ini sebanyak 12 Bumdes dan 2 Bumdesma kawasan dengan 12 desa. Dan dalam penelitian ini peneliti menggunakan teknik purposive sampling. Menurut Sugiyono (2012:126) teknik purposive sampling yaitu teknik penentuan sampel dengan pertimbangan tertentu.

f. Peneliti mengambil sampel atau nara sumber yang dianggap penting dan paling mengetahui tentang apa yang kita harapkan sehingga akan memudahkan peneliti dalam menjelajahi objek atau situasi sosial yang diteliti. Adapun jumlah populasi dalam penelitian ini sebanyak 12 Bumdes dan 2 Bumdesma kawasan dengan 12 desa.

\section{Desain Penelitian}

1. Desain penelitian merupakan suatu alat yang menuntun peneliti dalam melakukan penelitian. Dalam desain penelitian ini peneliti memiliki pedoman atau arahan dalam melakukan pengumpulan data, menganalisis dan menginterpretasikan atau menterjemahkan data yang dikumpulkan dan selanjutnya membuat kesimpulan.

2. Desain penelitian diawali dengan fokus masalah yang muncul pada Pemberdayaan Bundesma Menuju Desa Mandiri Masyarakat Warungkiara Sukabumi .

3. Dengan demikian, hasil dari interview dan observasi akan memberikan jawaban yang sangat bagus, menarik dan menyentuh, bahwa peranan Bumdesama dapat menghantarkan Masyarakat Warungkiara Sukabumi menuju Desa Mandiri . 


\section{Faktor pendukung Interview dan observasi}

1. Pemerintah desa serta Bumdes yang berada di kecamatan Warung Kiara Sukabumi Sebanyak 12 Bumdes 2 Bundesma kawasan.

2. Diprioritasan 2 Bumdes yang akan menjadi model yaitu :

a. Bumdes Sitaman Sakti ditetapkan oleh UNESCO sebagai kawasan Nasional. Bundes ini inisiatif dari Pemerintah Pusat (program 2020) dengan berbagai bantuan dari kementrian terkait, di antaranya akan dibangun Pasar Desa dan programnya agro wisata, yaitu budi daya mangga.

b. Bundesma Kiara Mandiri yang merupakan usaha UMKM masyarakat Desa di kecamatan Warungkiara dilakukan oleh kelompok-kelompok tani bercocok tanam singkok dan menjualnya kepada Bundesma ini yang mengolah menjadi Industry tapioca.

\section{Kriteria Interpretasi Temuan}

1. Data diperoleh dari sumber-sumber yang relevan dan bukan merupakan asumsi subjektif.

2. Data dapat diinterpretasikan dengan objektif, sesuai dengan fakta dan menghilangkan unsur bias dan kesalahan.

3. Data diperoleh dari informan kunci dengan Dari pemerintahan desa serta Bumdes dan Bundesma kawasan yang berada dikecamatan Warungkiara.

4. Menurut Sugiyono (2012:364) jika uji keabsahan data dalam penelitian kualitatif meliputi :

a. Uji credibility (validitas internal),

i. Meningkatkan ketekunan, yaitu dengan melakukan pengamatan secara lebih cermat dan berkesinambungan dengan mengecek data penelitian tentang peran Bundes dan Bundesma serta pemerintah Desa dalam mengawal Pemberdayaan Bundes dan Bundesma menuju Desa Mandiri Masyarakat Warungkiara Sukabumi . Dengan meningkatkan ketekunan maka, peneliti dapat memberikan deskripsi data yang akurat dan sistematis tentang apa yang diamati.

ii. Menggunakan Bahan Referensi, yang dimaksud dengan bahan referensi disini adalah adanya pendukung untuk membuktikan data yang telah ditemukan oleh peneliti. Dengan demikian, dalam penelitian ini peneliti menggunakan alat bantu camera dan alat perekam untuk mendapatkan data yang akurat dari wawancara

iii.Peninjauan kembali draft laporan studi kasus yang bersangkutan oleh key informan, yaitu dengan melihat keterkaitan yang eksplisit antara pertanyaan-pertanyaan yang diajukan, data yang terkumpul dan simpulan yang diambil.

iv. Diskusi teman sejawat, yakni diskusi yang dilakukan dengan rekan yang mampu memberikan masukan ataupun sanggahan sehingga memberikan kemantapan terhadap hasil penelitian. Teknik ini digunakan agar peneliti dapat mempertahankan sikap terbuka dan kejujuran serta memberikan kesempatan awal yang baik untuk memulai menjejaki dan mendiskusikan hasil penelitian dengan teman sejawat. 
Oleh karena pemeriksaan sejawat melalui diskusi ini bersifat informal dilakukan dengan cara memperhatikan wawancara melalui rekan sejawat, dengan maksud agar dapat memperoleh kritikan yang tajam untuk membangun dan penyempurnaan pada kajian penelitian yang sedang dilaksanakannya.

b. Transferability (validitas eksternal),

Dalam Sugiyono (2012:373) validitas eksternal menunjukkan derajat ketepatan atau dapat diterapkannya hasil penelitian ke populasi di mana sampel tersebut diambil dan bagi penelitian kualitatif nilai transfer bergantung pada pemakai, hingga manakala hasil penelitian tersebut dapat digunakan dalam konteks dan situasi sosial lain. Oleh karena itu, dalam penelitian ini supaya orang lain dapat memahami hasil penelitian sehingga ada kemungkinan untuk menerapkan hasil penelitian tersebut, maka peneliti dalam membuat laporannya dengan uraian yang rinci, jelas, dapat dipercaya dan dengan menggunakan bahasa yang mudah dipahami oleh pembaca.

c. Dependability (reliabilitas),

Dalam Danim (2002:205) dikemukakan bahwa untuk menentukan reliabilitas penelitian, dilakukan 4 hal.

i. Mengecek secara langsung keberhasilan penelitian.

ii. memperoleh keterangan atau menangkap fenomena penelitian dengan menerapkan berbagai metode.

iii.pencapaian keterandalan penelitian melalui replikasi.

iv. melalui pemeriksaan penelitian mirip dengan pemeriksaan pembukuan. Dalam keempat hal yang dikemukakan oleh Danim, tiga di antaranya yang digunakan dalam penelitian tentang Pemberdayaan Bundesma menuju Desa Mandiri Masyarakat Warungkiara Sukabumi, pertama mengecek secara langsung keberhasilan penelitian. Kedua, memperoleh keterangan, dan ketiga memeriksa penelitian mirip dengan memeriksa pembukuan (artikel, buku-buku dan jurnal).

d. Confirmability (obyektivitas).

Dalam Sugiyono (2012:374) dikemukakan bahwa pengujian objektivitas dalam penelitian berarti menguji hasil penelitian, dikaitkan dengan proses yang dilakukan. Oleh karena itu, dalam penelitian ini peneliti melakukan pengecekan dari data-data yang diperoleh baik dari observasi di lapangan, dan wawancara juga dari buku-buku yang terkait dengan Pemberdayaan Bundesma menuju Desa Mandiri Masyarakat Warungkiara Sukabumi Jika semua sudah sesuai atau sudah valid maka penelitian tersebut sudah memenuhi standar confirmability.

\section{Jenis dan Sumber Data}

Dalam penelitian ini, peneliti menggunakan jenis dan sumber data primer dan sekunder.

a. Jenis dan sumber data primer

Sumber data yang langsung memberikan data kepada pengumpul data, sedangkan jenis dan dalam penelitian ini sumber data primer yaitu dari 
wawancara dan observasi langsung para pengurus Bundesma dan aparat pemerintahan Desa serta Kecamatan dari lokasi penelitian.

b. Sumber data sekunder

Sumber data yang tidak langsung memberikan data kepada pengumpul data. Sugiyono (2012:308).

Dan data sekunder yaitu dari buku-buku, artikel dan jurnal yang berkaitan dengan Pemberdayaan Bundesma menuju Desa Mandiri Masyarakat Warungkiara Sukabumi.

\section{Teknik Pengumpulan Data}

Teknik pengumpulan data merupakan teknik untuk mengumpulkan data dari salah satu atau beberapa sumber data yang ditentukan. Untuk memperoleh datadata yang lengkap dan relevan, maka penulis menggunakan teknik pengumpulan data wawancara, observasi dan Dokementasi sebagai mana dijelaskan sebagai berikut :

1. Wawancara

Tehnik wawancara digunakan karena mempunyai beberapa kelebihan, antara lain dikemukakan oleh James A Black dan Dean J . Champion , Metode Penelitian Sosial / terjemahan E Kuswara, Dira Salam dan Alvin Ruzhendi ( Bandung: PT Etresco, 1992) h.51. sebagai berikut:

i. Dapat digunakan peneliti untuk lebih cepat memperoleh informasi yang dibutuhkan.

ii. Lebih meyakinkan peneliti bahwa responden menafsirkan pertanyaan dengan benar.

iii.Memberi kemungkinan besar atas keluwesan dalam proses pengajuaan pertanyaan.

iv. Banyak pengendalian yang dapat dilatih dalam konteks pertanyaan yang diajukan dan jawaban yang diberikan.

v. Informasi dapat lebih siap diperiksa ke sahihannya atas dasar isyarat non verbal.

Menurut Robert K Yin dalam bukunya Case Study Research : Design and Methods (California : SAGE Publicatons, Inc, 2009) hh. 106-07 wawancara dilakukan secara :

i. Open-ended

Peneliti bertanya kepada informan kunci tentang fakta-fakta suatu peristiwa dan opini mereka mengenai peristiwa yang ada

ii. Terfokus

Responden diwawancarai dalam waktu yang pendek.

iii. Terstruktur

Mengunakan pertanyaan yang tersstruktur.

Dalam penelitian ini langkah - langkah yang dilakukan terkait dengan wawancara sebagaiberikut :

i. Membuat Pedoman Wawancara

Pedoman wawancara dikembangkan dari pertanyaan-pertanyaan peneliti secara lebih rinci, sehingga dapat memberikan jawaban yang konfrehensif atas pertanyaan-pertanyaan peneliti yang diajukan . 
Pedoman wawancara digunakan sebagai acuan peneliti pada saat melakukan wawancara dengan para informan. Dalam hal ini peneliti menyerahkan lembaran pertanyaan-pertanyaan kepada informan jika tidak memeiliki waktu untuk menjawab secara langsung dan agar lebih leluasa dalam memberikan jawaban.

ii. Membuat janji dengan para informan, peneliti terlebih dahulu menelpon atau menemui langsung informan untuk mengeahui waktu luang untuk wawancara, sehingga dapat ditetapkan waktu dan tempat wawancara.

iii. Melakukan wawancara

Sebelum melakukan wawancara, peneliti menyiapkan sebuah peralatan yang dibutuhkan untuk wawancara, peralatan tulis,alat perekam dll.

iv. Melakukan transkrip hasil wawancara yang selanjutnya dijadikan bahan untuk analisis data.

Wawancara dalam penelitian ini dilakukan dengan informan penelitian. Informan dalam penelitian kualitatif berperanan sangat penting untuk keberhasilan penelitian. Informan yang diperlukan terutama informan kunci (Key informan) .

Menurut J. Kevin Eckert dan Sheryl I Zimmerman, Maximazing Methods : Interviewers as Informants, eds Graham D . Rowles dan Nancy E Schoenberg (New York : Springer Publishing Company, inc.,2002), h.200 menyatakan bahwa informasi kunci adalah subjek penelitian yaitu orang atau anggota kelompok yang dipelajari yang bertindak sebagai petunjukdan menginterprestasikan adat istiadat budaya, prilaku individu dan kelompok jargon dan Bahasa.

Informasi kunci adalah subjek penelitian yang memahami masalahmasalah yang diteliti, sehingga dapat memberikan informasi-informasi penting dan relevan sesuai yang dibutuhkan.

Informasi kunci yang dilibatkan dalam penelitian in adalah pihak-pihak yang terkait dalam Pemberdayaan Bundesma menuju Desa Mandiri Masyarakat Warungkiara Sukabumi yaitu Pengurus - pengurus Bundesma, petani singkong dan aparat pemerintahan Desa dan Kecamatan Warungkiara.

2. Observasi.

Observasi adalah suatu proses melihat, mengamati, mencermati, dan merekam perilaku secara sistematis untuk suatu tujuan tertentu. Inti dari observasi adalah adanya perilaku yang tampak dan tujuan yang ingin dicapai. Perilaku yang tampak dapat berupa perilaku yang dapat dilihat oleh mata, didengar, dihitung atau dapat diukur. Herdiansyah (2012:53). Dalam pelaksanaannya peneliti mengamati kegiatan yang dilakukan oleh subjek dan mengamati subjek dalam menjawab pertanyaan-pertanyaan peneliti selama wawancara berlangsung. Observasi diartikan sebagai pengalaman dan pencatatan secara sistematis terhadap segala yang tampak pada objek penelitian, dengan menggunakan observasi terus terang atau tersamar, dalam hal ini, peneliti dalam pengumpulan data menyatakan 
terus terang kepada sumber data, bahwa peneliti sedang melakukan penelitian.

3. Dokumentasi.

Dokumentasi dilakukan dengan mengumpulkan dokumen-dokumen atau bahan-bahan sebagai sebagai data sekunder yang relevan dengan tema yang sedang diteliti. Dokumen-dokumen yang diperlukan seperti peraturan perundang-undangan, hasil laporan. Disamping itu peneliti juga mendokumentasikan kegiatan-kegiatan penting dengan mengunakan kamera sebagai bukti otentik dari suatu kejadian yang ada hubungannya dengan permasalahan penelitian.

\section{PEMBAHASAN}

Pemberdayaan Bundesma artinya adalah proses pembangunan di mana Bundesma berinisiatif untuk memulai proses kegiatan Sosial Ekonomi untuk memperbaiki situasi dan kondisi perekonomian masyarakat Desa di wilayah kecamatan Warungkiara. Dalam Pemberdayaan masyarakat tersebut tampak partisipasi Bundes dan masyarakat desa sebagai agen pembangunan yaitu motor pengerak pembangunan ekonomi dikawal oleh Pemerintah Desa.

Sehubungan dengan program pemerintah untuk mengentaskan kemiskinan di Pedesaan telah dikeluarkan berbagai kebijakan pemerintah pusat yang dapat dipergunakan sebagai stimulus untuk memperbaiki situasi dan kondisi perekonomian masyarakat desa, diantaranya keberadaan Bundes diakui sebagai Badan Usaha Milik Desa berdasarkan pada Undang-Undang No. 32 Tahun 2004 tentang Pemerintahan Daerah pasal 213 menyebutkan bahwa BUMDes adalah badan hukum .

Sebagai Badan Hukum BUMDes diharapkan dapat menjadi Badan Usaha yang mencari profit untuk kepentingan masyarakat Desa. Terkait dengan Bundes maupun Bundesma yang terdapat di Warungkiara Sukabumi merupakan usaha UMKM, Pelaku usaha tergabung dalam pemberdayaan usaha rakyat yang diwujudkan dalam Badan usaha milik desa (BUMDES) lokal dan kawasan serta Badan usaha milik desa bersama (BUMDESMA). Dengan adanya Badan usaha milik desa ini sangat berarti bagi kesejahteraan masyarakat desa, karena memberikan manfaat yang begitu besar seperti mampu membantu masyarakat dalam mengenal dan memanfaatkan potensi yang ada, membuka lapangan pekerjaan, dan lain sebagainya.

Di Kecamatan Warungkiara terdapat 12 Desa masing ada Bundes yaitu :

1. Bundes desa Hegarmanah

2. Bundes desa Bantarkalong

3. Bundes desa Dinarjaya

4. Bundes desa Bojongkerta

5. Bundes desa Ubrug

6. Bundes desa Girijaya

7. Bundes desa Warungkiara

8. Bundes desa Sukaharja 
9. Bundes desa Tarisi

10. Bundes desa Damaraja

11. Bundes desa Kertamukti

12. Bundes desa Mekarjaya

Disamping itu terdapat 2 Bundes Bersama (Bundesma) yaitu :

1. Bundesma Garuda Jaya

2. Bundesma Kiara Mandiri

\section{Permasalahan yang dihadapi oleh Bundes dan Bundesma}

Hasil Observasi dan Wawancara dengan Pengurus Bundes, Bundesma dan petani yang tergabung dalam kelompok Tani singkong, Pemerintahan Desa serta Pemerintahan Kecamatan Warungkiara dalam memberdayakan Bundes maupun Bundesma terdapat beberapa persoalan yang menghabat, yaitu :

\section{Kesulitan pemasaran}

Sebagaimana usaha yang berskala kecil Salah satu aspek yang terkait dengan masalah pemasaran yang umum dihadapi oleh pengusaha UKM adalah tekanan-tekanan persaingan, baik dipasar domestik dari produk-produk yang serupa buatan pengusaha-pengusaha besar dan impor, maupun dipasar ekspor. Sehubungan dengan hal tersebut bagaimanakah cara mengatasi kesulitan pemasaran perlu dilakukan :

a. Mengenal Pasar dan Target Market

Mengenal pasar dalam hal ini harus mengetahui kualitas dan kegunaan produk yang akan dijual. Apakah produk merupakan produk baru atau sudah banyak yang menjual? Ini perlu menjadi pertimbangan untuk mengatur strategi pemasaran produk.

Jika produk merupakan produk yang baru, maka memiliki jangkauan area yang luas untuk memasarkan produk. Namun jika produk yang dijual sebenarnya sudah banyak kompetitor, maka perlu mengenal lebih jauh kelemahan-kelemahan produk yang dijual oleh saingan dan memperbaikinya di produk yang akan di jual untuk mendapatkan perhatian konsumen. Konsumen tentu lebih tertarik dengan produk yang memiliki lebih banyak kelebihan daripada kelemahnnya. Dalam Pemberdayaan Bundes maupun Bundesma tampak bahwa belum mengenal pasar yang akan menjadi sasaran penjualan produk yang dihasilkan oleh masyarakat diantaranya Singkong yang jumlahnya sangat banyak, seharusnya jika pangsa pasar untuk domestic dan luar negeri dapat dimasuki oleh Bundes ataupun Bundesma dengan bantuan pemerintah Pusat maupun pemerintah daerah maka sasaran / target market produk yang akan dijual akan terserap oleh pasar sehingga hasil usaha Bundes maupun Bundesma menguntungkan masyarakat Desa.

b. Menciptakan Produk Berkualitas

Membuat produk berkualitas dan sesuai dengan target market yang akan dibidik adalah sebuah awal yang baik untuk memulai usaha Bundes dan Bundesma . Demikian halnya yang dilakukan oleh Bundes dan Bundesma menciptakan produk hasil karya masyarakat Desa yang 
berkualitas mulai dari bahan baku, proses pembuatan, hingga tercipta sebuah produk.

Dengan membuat produk yang berkualitas, maka dengan sendirinya telah membantu proses pemasaran itu sendiri. Alasannya, karena semua orang lebih memilih produk yang berkualitas ketimbang produk yang abal-abal. Proses pembuatan produk berkualitas ini sendiri tidak bisa terjadi begitu saja. Tentunya butuh waktu untuk mereview produk yang sudah dihasilkan hingga akhirnya benar-benar sesuai dengan yang diharapkan.

c. Membuat Kemasan Menarik untuk Produk

Salah satu strategi pemasaran produk harus memperhatikan segala aspek, termasuk kemasan produk yang dijual.

Kemasan produk tidak sekedar tampilan saja, namun harus ada sesuatu yang dapat membuat produk terkesan oleh konsumen. Ada banyak konsumen yang lebih mudah mengingat sebuah produk karena kemasan produk tersebut sangat berkesan. Oleh sebab itu diperlukan desain kemasan produk. Sehubungan dengan hal tersebut dibutuhkan tenaga desainer berbakat.

d. Memilih Lokasi Pemasaran yang Tepat

Macam-macam Produk yang dihasilkan oleh 12 Bundes maupun Bundesma di Kecamatan Warungkiara biasanya dilakukan pemasaran pada masing-masing desa, dalam hal ini pembeli/konsumen yang datang ke lokasi.

e. Tawarkan Promo

Di jaman yang serba mahal ini sudah pasti banyak orang yang menyukai adanya promo produk atau sale.

Promo ini terbilang ampuh karena akan menarik perhatian calon pembeli yang awalnya hanya ingin coba-coba justru bisa menjadi pelanggan tetap karena kualitas produk yang tawarkan. Promo seperti ini tentu harus didasari perhitungan untung rugi. Jangan sampai karena adanya over promo justru membuat bangkrut. Solusinya bisa membatasi promo misalnya hanya berlaku untuk 2 atau 3 hari saja.

f. Manfaatkan Tenaga Pelanggan

Satu lagi cara promosi yang paling jitu adalah dengan memanfaatkan tenaga pelanggan, yaitu menawarkan sistem bagi hasil bagi pelanggan yang mau menawarkan produk ke konsumen lain .

g. Manfaatkan Media Online

Hampir sebagian masyarakat kita sudah pasti punya gadget atau smartphone, sehubungan dengan kondisi tersebut maka bisa melakukan pemasaran atau memasang iklan di website, market place atau beberapa sosial media seperti Instagram, Facebook, dan Twitter. Kunjungi market place terpercaya seperti Tokopedia, Kaskus, OLX, atau sejenisnya yang biasa digunakan secara gratis atau berbayar bila ingin menikmati fitur premium.

h. Menjadi Sponsor Sebuah Kegiatan 
Strategi pemasaran produk dengan cara menjadi sponsor kegiatan ternyata sangat efektif . Cara pemasaran seperti ini bisa dilakukan secara online maupun offline.

i. Memberikan Insentif untuk Rekomendasi Pelanggan Strategi pemasaran produk dengan cara word of mouth (promosi dari mulut ke mulut) adalah salah satu cara pemasaran yang sangat efektif. Karena promosi seperti ini biasanya lebih mudah dipercaya orang lain karena direkomendasikan oleh orang yang dikenal.

Insentif kepada konsumen yang mau merekomendasikan produk kepada teman atau kerabatnya biasanya diberikan berupa voucher, kupon diskon, uang, atau bahkan produk.

j. Melakukan Kegiatan Amal (Corporate Social Responsibility)

Yaitu Kepedulian kepada masyarakat sekitar/relasi komunitas sebagai peningkatan partisipasi di dalam sebuah komunitas melalui berbagai upaya kemaslahatan

\section{Keterbatasan financial}

Masalah mendasar yang harus segera dientaskan dan harus menjadi prioritas utama dalam pemberdayaan Bundes dan Bundesma di Kecamatan Warungkiara adalah masalah pengelolaan keuangan. Sehubun gan dengan hal tersebut dalam rangka Pemberdayaan Bundesma menuju Desa Mandiri Masyarakat Kecamatan Warungkiara Sukabumi perlu dilakukan pelatihan dan pendampingan bagaimana cara membuat Laporan Keuangan .

Bundes dan Bundesma serta Kelompok Tani sebagai pelaku UMKM harus diarah pengentasan masalah kebelum pahaman pengelolaan keuangan usaha, karena hasil observasi dan wawancara dengan pengurus Bundes dan masyarakat bahwa sebagian besar tidak mencatat setiap transaksi yang dilakukan baik harian, mingguan dan bulanan, sehingga tidak memiliki laporan Keuangan .

Pernyataan tersebut dikemukakan oleh para pengurus Bundes dan Bundesma serta Kelompok Petani Singkong pada tanggal 11 September 2019 dalam rangka pelaksanaan Pengabdian Kepada Masyarakat (PKM) di Kantor Kecamatan Warungkiara RT 03. Berkenaan dengan kondisi tersebut telah diberikan pelatihan pembukuan sederhana sesuai dengan standar pelaporan keuangan khusus UKM atau UMKM (Usaha Mikro Kecil Menengah) yang bisa dijadikan contoh. Tetapi tampaknya tidak cukup hanya Pelatihan saja, perlu dilakukan pendampingan oleh Universitas Pamulang kepada Bundes dan Bundesma serta kelompok Tani agar dapat membuat Laporan keuangan.

3. Keterbatasan Sumber Daya Manusia (SDM)

Keterbatasan sumber daya manusia juga merupakan salah satu kendala serius bagi Bundesma di Warungkiara, terutama dalam aspek-aspek kewirausahaan, manajemen, teknik produksi, pengembangan produk, control kualitas, akuntansi, Semua keahlian tersebut sangat diperlukan untuk mempertahankan atau memperbaiki kualitas produk, meningkatkan efisiensi dan produktifitas dalam produksi, memperluas pangsa pasar dan menembus pasar baru. 


\section{Proses Pengelolaan Keuangan}

Proses Pengelolaan Keuangan untuk Bundes dan Bundesma serta Kelompok Tani sebagai pelaku UMKM di Kecamatan Warungkiara pada umumnya belum dilakukan dengan baik karena :

1. Pertama belum adanya pemisahan keuangan antara uang usaha dan uang untuk menutup kebutuhan hidup harian. Fenomena ini seringkali terjadi karena pelaku UMKM menganggap usahanya masih kecil dan bersifat usaha keluarga. Toh kata mereka, uang hasil usaha ini pula yang mereka pakai untuk memenuhi kebutuhan sehari-hari.

Padahal, usaha memerlukan akumulasi modal yang diambil dari keuntungan, guna memastikan usaha itu semakin berkembang atau tidak. Kebutuhan keuangan harian memang boleh dipenuhi dari keuntungan usaha yang tercipta. Namun harus punya batas yang jelas. Yakni sebesar laba bersih dikurangi target keuntungan yang ditargetkan kembali masuk sebagai penambah modal. Sirkulasinya boleh saja harian, mingguan, ataupun bulanan.

2. Kedua, kondisi di atas menyebabkan para pelaku tidak pernah tahu seberapa besar keuntungan usaha mereka. Berapa persen laba bersih mereka. Kalimat 'yang penting bisa makan' adalah jawaban yang paling sering didengar ketika bicara soal keuntungan kepada pelaku UMKM. Sikap yang 'asal' ini yang menyebabkan mereka tidak kunjung profesional. Artinya, jika keuntungan usaha jauh dari nilai wajar maka keuntungan sebuah produk, penetapan ulang harga jual atau negosiasi harga perolehan bahan baku harus segera dilakukan.

3. Ketiga, masih banyak pelaku UMKM termasuk Bundes dan Bundesma yang merasa tidak perlu menyusun laporan keuangan sesederhana apapun sebagai bahan analisa kegiatan usahanya. Alasan mereka, yang penting uang hasil penjualan hari ini bisa untuk modal lagi keesokan harinya. Padahal tidak bisa begitu. Selamanya usaha tersebut tidak akan berkembang jika hal-hal keuangan yang kecil tidak mulai diperhatikan sejak awal.

4. Keempat, kacaunya manajemen keuangan ketika pelaku UMKM sudah terlibat dalam hubungan utang dagang dan atau utang ke lembaga keuangan. Karena hubungan utang piutang (apalagi yang bersifat formal kelembagaan) selalu menciptakan konsekuensi. Konsekwensi dapat berupa denda (pinalty), bunga berbunga, atau bahkan penyitaan dan penjualan agunan tambahan. Padahal ketidakmampuan itu belum tentu berasal dari tidak profit-nya usaha atau tidak terpenuhinya margin keuntungan minimal, namun lebih karena ketidak profesionalan mereka mengelola cash in dan cash out usaha.

\section{Mewujudkan Akuntabilitas Keuangan Bundes}

Akuntabilitas modal utama membangun kepercayaan public. Terkait dengan penyusunan laporan keuangan Bundes di Warungkiara ini sebagaimana tersebut di atas dalam pelaksanaan Pengabdian Masyarakat yang telah kami lakukan dialog dengan pengurus Bundes dan Bundesma serta kelompok Tani serta aparatur Desa bahwa dalam rangka Pemberdayaan menuju Desa Mandiri dibutuhkan pendampingan dalam membuat laporan keuangan . 
Proses pendampingan harus dilakukan dengan MOU antara Universitas Pamulang Fakultas Ekonomi Akutansi dengan 12 Bundes dan 2 Bundesma yang terdapat dikecamatan Warungkiara. Proses Pendampingan untuk Bundes sebagai pelaku UMKM mengunakan standar Akutansi EMKM (Entitas Micro Kecil Menengah Macro), yang sengaja dirancang untuk Patokan standar Akuntansi Keuangan pada UMKM.

\section{Aspek Finansial Bundes}

Berdasarkan wawancara dan observasi di lapangan Bundes dan Bundesma yang terdapat di Kecamatan Warungkiara menghadapi dua masalah utama dalam aspek finansial antara lain:

a. modal (baik modal awal maupun modal kerja)

b. finansial jangka Panjang untuk investasi yang sangat diperlukan untuk pertumbuhan output jangka panjang.

Keterbatasan modal sebenarnya dapat diatasi dengan bergandengan tangan dengan bank ataupun pemerintah yang saat ini sedang getol-getolnya melempar program mengentaskan kemiskinan. Untuk dapat mengikuti program pemerintah maupun pinjaman ke bank Bundes, Bundesma dan kelompok Tani harus dapat menyajikan laporan keuangan

\section{KESIMPULAN}

Dalam Pemberdayaan Bundes dan Bundesma untuk masyarakat desa di Kecamatan Warungkiara Sukabumi harus dikawal oleh Pemerintah Desa dan Pemerintahan Kecamatan Warungkiara Sukabumi.

Upaya Pemberdayaan Bundes dan Bundesma untuk masyarakat desa di Kecamatan Warungkiara Sukabumi menghadapi kendala yang harus diatasi bersama yaitu meliputi:

1. Kesulitan pemasaran

Sebagaimana usaha yang berskala kecil Salah satu aspek yang terkait dengan masalah pemasaran yang umum dihadapi oleh pengusaha UKM adalah tekanan-tekanan persaingan, baik dipasar domestik dari produk-produk yang serupa buatan pengusaha-pengusaha besar dan impor, maupun dipasar ekspor.

2. Keterbatasan financial

Bundesma di Warungkiara menghadapi dua masalah utama dalam aspek finansial, diantaranya keterbatasan modal sebenarnya dapat diatasi dengan bergandengan tangan dengan bank ataupun pemerintah yang saat ini sedang getol-getolnya melempar program mengentaskan kemiskinan. Untuk dapat mengikuti program pemerintah maupun pinjaman ke bank para pelaku harus mempunyai kapasitas membuat laporan keuangan. Persoalannya disini para petani maupun anggota Bundes sebagian besar tidak mencatat setiap transaksi yang dilakukan, sehingga tidak bankable

3. Keterbatasan Sumber Daya Manusia (SDM)

Keterbatasan sumber daya manusia juga merupakan salah satu kendala serius bagi Bundesma di Warungkiara, terutama dalam aspek-aspek kewirausahaan, 
manajemen, teknik produksi, pengembangan produk, control kualitas, akuntansi, semua keahlian tersebut sangat diperlukan untuk mempertahankan atau memperbaiki kualitas produk, meningkatkan efisiensi dan produktifitas dalam produksi, memperluas pangsa pasar dan menembus pasar baru.

\section{REFERENCES}

Anggaran Dasar (AD) Badan Usaha Milik Desa (BUMDes) Desa Ponggok Kecamatan Polanharjo Kabupaten Klaten

Ari Hermawan dan Murti Pramuwardhani Dewi (2013), Pemberangusan Serikat Pekerja di Daerah Istimewa Yogyakarta, Jurnal Hukum Yustisia, Edisi 86 (Mei-Agustus, 2013)

Chambers, Robert (1988), Pembangunan Desa Mulai dari Belakang, Jakarta, LP3ES (Lembaga Penelitian, Pendidikan, dan Penerangan Ekonomi dan Sosial)

Departemen Pendidikan Nasional Pusat Kajian Dinamika Sistem Pembangunan (PKDSP) (2007), Buku Panduan Pendirian dan Pengelolaan Badan Usaha Milik Desa (BUMDes), Jakarta, Fakultas Ekonomi Universitas Brawijaya

Gunawan, Ketut (2011), Manajemen BUMDes dalam Rangka Menekan Laju Urbanisasi, Widyatech Jurnal Sains dan Teknologi. Volume 10 Nomor 3. April 2011

Ibrahim, Jhonny (2006), Teori dan Metodologi Penelitian Hukum Normatif, Malang, Banyumedia Publishing

Jonnius (2014), Analisis Kinerja Karyawan BUMDes di Kabupaten Kampar, Jurnal Penelitian Sosial Keagamaan,. Volume 17 Nomor 1. JanuariJuni, 2014

Khudzaifah Dimyati dan Kelik Wardiono (2015), Metode Penelitian Hukum (Buku Pegangan Kuliah), Surakarta, Universitas Muhammadiyah Surakarta

Mubyarto dan Sartono Kartodirdjo (1988), Pembangunan Pedesaan di Indonesia, Yogyakarta, Liberty Yogyakarta

Mas Achmad (2007), Kewajiban Tanggung Jawab Sosial Perusahaan dalam Undang-Undang Perseroan Terbatas, Jakarta, KadinSlide Presentasi BUMDes Tirta Mandiri Klaten

N. Daldjoeni dan A. Suyitno (1986), Pedesaan, Lingkunngan, dan Pembangunan. Bandung: Alumni, hal. xiv

Nancy (2011), Tinjauan Hukum Tanggung Jawab Sosial Perusahaan (Corporate Social Responsibility/CSR)." Jurnal Sasi, Vol. 17, No.4. (OktoberDesember, 2011)

Putriyanti, Ayu. (2015), Kajian Undang-Undang Administrasi Pemerintahan dalam Kaitan dengan Pengadilan Tata Usaha Negara," Jurnal Pandecta, Volume 10, Nomor 2 (Desember, 2015)

Peraturan Pemerintah No. 72 tahun 2005 tentang Desa 
Peraturan Menteri dalam Negeri Nomor 39 tahun 2010 tentang Badan Usaha Milik Desa

Peraturan Menteri Desa Nomor 4 tahun 2015 tentang Pendirian, Pengurusan dan Pengelolaan dan Pembubaran Badan Usaha Milik Desa

Peraturan Desa Ponggok Nomor 6 tahun 2009 tentang Badan Usaha Milik Desa

Sugihen.T, Bahrein (1996), Sosiologi Pedesaan (Suatu Pengantar). Jakarta, PT Raja Grafindo Persada

Soerjono Soekanto dan Abdul Rahman (2003), Metode Penelitian Hukum. Jakarta: Rineka Cipta

Undang-Undang Dasar Negara Republik Indonesia Tahun 1945

Undang-Undang No. 6 tahun 2014 tentang Desa

Undang-Undang No. 23 tahun 2014 tentang Pemerintahan Daerah

Zulkarnain Ridlwan (2013), Payung Hukum Pembentukan BUMDes, Fiat Justitia Jurnal Ilmu Hukum Vol 7, No.3 (September-Desember, 2013) 